\title{
A Native American Girl's Coming of Age in Louise Erdrich's The Porcupine Year
}

\author{
Li Ping Chang (Corresponding author) \\ Department of Applied Foreign Languages, National Taipei College of Business \\ No.321, Sec. 1, Jinan Rd., Zhongzheng District, Taipei City 100, Taiwan \\ Tel: 886-2-2322-6430Ｅ-mail: floraliping@webmail.ntcb.edu.tw
}

En Yin Chou

Department of Applied Foreign Languages, National Taipei College of Business

No.321, Sec. 1, Jinan Rd., Zhongzheng District, Taipei City 100, Taiwan

Tel: 886-2-2322-6430Ｅ-mail: angel3533827@gmail.com

\author{
Yi Hua Yang \\ Department of Applied Foreign Languages, National Taipei College of Business \\ No.321, Sec. 1, Jinan Rd., Zhongzheng District, Taipei City 100, Taiwan \\ Tel: 886-2-2322-6430_E-mail: yh9523@hotmail.com
}

\author{
Received: May 12, 2011 \\ Accepted: May 30, $2011 \quad$ Published: October 1, 2011 \\ doi:10.5430/wjel.v1n2p43 \\ URL: http://dx.doi.org/10.5430/wjel.v1n2p43
}

\begin{abstract}
Louise Erdrich, one of the most renowned Native American authors of our time, writes a female Bildungsroman in The Porcupine Year, a sequel to The Birchbark House and The Game of Silence. The story follows the 12-year-old Native American girl Omakayas as she makes the journey from childhood toward womanhood during the porcupine year, the year named for her younger brother's medicine animal. During this year that Omakayas travels with her family, looking for a new home after being forced off their land, she will fight with an eagle, endure betrayal and starvation and the death of her beloved friend Old Tallow. She will also fall in love, learn about healing from her grandmother Nokomis, and begin to realize her own gifts in this area. These experiences mark another stage in her coming of age. This paper will use Carl Jung's psychoanalytic theories, Erik H. Erikson's theory on psychosocial development, Carenlee Barkdull's on Native American women's identity, and Michael Garrett and J. T. Garrett's observations on Native American children's education to explore Omakayas's identity development.
\end{abstract}

Keywords: Native American girl, Identity development, Bildungsroman

\section{Introduction}

A member of the Turtle Mountain Chippewa tribe, Louise Erdrich has said that her works are firmly grounded in tribal traditions, culture, and spirituality. Her "fiction and poetry draw on her Chippewa heritage and experiences as a Native American to examine complex family and sexual relationships among full- and mixed-blood Native Americans as they struggle with questions of identity in white American culture" (Rozakis, 1999, p. 381). Moreover, Erdrich's works particularly focus on "family life and relationships" (Thompson, 2001, p. 369). As evidence of her storytelling ability, Erdrich often imperceptibly incorporates colonial/tribal histories with the events her main characters live through. In this way she articulates the significance of such events in the process of her characters' identity formation. Erdrich tells native stories which emerge in "a confusion of loss, a tale of absences, of a culture that was blown apart and changed so radically in such a short time" (Valaskakis, 2005, p. 115). The Porcupine Year (2008), a sequel to The Game of Silence (2005) and The Birchbark House (1999), is the last book in Erdrich's trilogy of a Native American girl's coming of age. In The Porcupine Year, the protagonist and her family have been forced from their home by the US government, and are making the journey to find a new home. Throughout the journey, the 12-year-old protagonist Omakayas and her family, encounter great hardship and privation. Omakayas's suffering is both physical and mental, and includes near starvation and the death of a beloved adult, as well as jealousy in a budding love affair. The incident at the beginning of the novel, 
where she and her brother are paddling their canoe in a rapid river, and "soon realized that they' $\mathrm{d}$ been tugged into the confluence of two rivers" (Erdrich, 2008, p. 3) in part foreshadows her journey in the following year: she will be pulled into events not of her own making.

\section{Bildunsroman}

Omakayas is portrayed as a warrior. She will undergo this journey in a spirit of adventure. She is ready for this stage in her development:

Omakayas was no longer a little girl. She was that creature somewhere between a child and a woman-a person ready to test her intelligence, her hungers. A dreamer who did not yet know her limits. A hunter, like her brother who was beginning to possess the knowledge of all that moved and breathed. A friend who did not know how far her love might extend. A daughter who still winced at her mother's commands and who loved and shyly feared her distant father. A girl who'd come to know something of her strength and who wanted challenge, and would get it, in the years of her family's exile from their original home - the Island of the Golden-Breasted Woodpecker. (ibid., p. 10)

Erdrich charts the progress of her innocent protagonist as Omakayas is tugged into the trials and tribulations that become lessons of her childhood. Despite the difficulty and pain of many of these experiences, they have deep meaning, and help to awaken her to who she is, and who she might become. In this way The Porcupine Year is a female Bildungsroman, describing the coming of age of a female hero in her journey from innocence to experience, toward full-fledged identity-development.

A Bildungsroman uses at least two or three of the following elements: "childhood, the conflict of generations, provinciality, the larger society, self-education, alienation, ordeal by love, the search for a vocation and a working philosophy" (Buckley, 1974, p. 18). Traditionally, in a Bildungsroman, the young, inexperienced, and naïve protagonist has a variety of experiences and learns from them. Eventually, he or she becomes a wiser person, and one more capable of living in the world. There are actually obvious differences between male and female Bildungsroman. Sidonie Smith and Julia Watson (2001) employ C. Hugh Holman's statement that this "apprenticeship novel... recounts the youth and young manhood of a sensitive protagonist who is attempting to learn the nature of the world, discover its meaning and pattern, and acquire a philosophy of life and "the art of living"' (p. 189). Smith and Watson go on to state that the plot "may involve escape from a repressive family, schooling, and a journey into the wide world of urban life where encounters with a series of mentors, romantic involvements, and entrepreneurial ventures lead the protagonist to reevaluate assumptions" (2001, p. 189). The female Bildungsroman also blazes a path to self-discovery but through other plot conventions. Unlike the male heroes, who test their self-image "through adventure in the outside world," female heroines "are initiated at home through learning the rituals of human relationships, so that they may replicate the lives of their mothers" (Ferguson, 1983, p. 229). Further, "the familiar evaluation of a young woman's development that poses the question" of her marriage is a premise sharply challenged in the theoretical setting of the female Bildungsroman" (Labovitz, 1988, p. 7).

Although the Bildungsroman has fallen in and out of fashion, Bonnie Hoover Braendlin points out that "[i]n contemporary American literature, .... the Bildungsroman is being resuscitated, revived...by societal outsiders, men and women of marginality groups" (1984, p. 75) and that ethnic women writers have created a "new Bildungsroman [which] asserts an identity defined by the outsiders themselves or by their own cultures, not by the patriarchal Anglo-American power structure; it evinces a revaluation, a transvaluation, of tradition Bildung by new standards and perspectives" (ibid., p. 75). Many heroines in twentieth-century Bildungsroman are "introspective 'confessors' rather than adventuring "picaros" (ibid., p. 84). The Bildungsroman that portrays the development of ethnic women emphasizes that they "explore in their literature avenues to a self-defined identity" and "an affirmation of personal and social goals, values, and ideals" (ibid. p. 86). In The Porcupine Year, Omakayas is educated by her elders, and the self she is taught to present is partly formed with their values in mind. This article aims to explore how Omakayas achieves this. To illustrate the processes of Omakayas's coming of age, I shall use Carl Jung's psychoanalytic theories, Erik H. Erikson's theory on psychosocial development, Carenlee Barkdull's on Native American women's identity, and Michael Garrett and J. T. Garrett's observations on Native American children's education.

\section{Methodology}

\subsection{Carl Jung's theory on psychoanalysis}

Before discussing Omakayas's story, I will present their ideas in brief. B. B. Wolman (1973) interprets Carl Jung's conception of the collective unconscious as follows:

The part of the unconscious composed of acquired traits and cultural patterns transmitted by heredity is the 
foundation of the whole personality structure. It is universal, all men [sic] being essentially the same, is almost totally divorced from anything personal or individual, and is continuously accumulating memory traces as a result of man's repeated experiences. Archetypes are its structural components. (p. 328)

The chief archetypes of concern in The Porcupine Year are the persona and the shadow. Carl Jung defines the persona as "a complicated system of relations between the individual consciousness and society, fittingly enough a kind of mask, designed on the one hand to make a definite impression upon others, and, on the other, to conceal the true nature of individual" (1982, p. 81). The shadow "makes one feel guilty about oneself. Or, alternatively, it may cause one to perceive evil in others" (ibid. p. 156).

\subsection{Erik Erikson's discourse on psychosocial development}

Erik Erikson (1950) divides psychosocial development into eight stages from infancy to late adulthood; he asserts that a healthily developing person should pass through and confront new challenges in each stage. Adolescents are in psychosocial crisis because they are confused about their identity, the role they play, and how they appear in the eyes of others. Their virtues or strengths appear in response to what they learn through experience.

\subsection{Carenlee Barkdull's theory on Native American Women}

Carenlee Barkdull's theory on Native American women suggests five themes on identity in stories about native women; two are particularly significant in The Porcupine Year: knowing 'who I am,' and turning points (2009, p. 128). Several of the incidents in the book are turning points that make Omakayas stronger and more mature, while knowing herself is both an outcome and a way of handling the challenges of her life. Barkdull (2009), who defines turning points as "early life influences, significant people, and significant life events", writes of their developmental importance:

Turning points were imbued with meaning and purpose. Although the events at the time may have been extremely painful or even devastating in some cases, they were usually regarded as positive or necessary in retrospect. Such events may have strengthened a woman's sense of independence, motivation to achieve, and perseverance in the face of setbacks or helped her consciously to make healthier choices for herself. (pp. 129-130)

An early turning point in The Porcupine Year occurs when Omakayas notices an eagle's interest in the meat her family has hung up to dry. Knowing that eagle feathers are powerful medicine, she hides under the drying racks until the eagle swoops down for the meat, and succeeds in taking four pure white feathers from the eagle, despite its ferocity. The eagle fights with claw and beak but Omakayas holds onto it until she can take the feathers; she succeeds through cunning and courage. Not only does Omakayas win the feathers, her father Deydey says that she has performed a warrior's deed, and that she is no longer a child and deserves a feast.

Omakayas felt something balloon up inside of her like a cloud. It was strange, buoyant feeling - she felt that she could be lifted away by it. As if she'd held on to an eagle and been dragged up into the air! After Deydey left, she understood what it was - pride. It was so rare that Deydey ever showed that he was proud of what she'd done. (Erdrich, 2008, p. 54)

In this instance Omakayas is also getting a sense of one of Barkdull's (2009) other themes in identity development, that of- "knowing who I am":

At some point, each woman used this or a similar phrase ["knowing who I am"] to refer to a deliberate, conscious, and ongoing reflective process. For the women, this aspect of identity —of defining oneself on one's own terms - could not be taken for granted but was constantly negotiated and renegotiated in facing the tasks and challenges of daily living. (pp. 129-130)

There are three subtheme divided under the theory of "knowing who I am". The first one is the strong bond in the Native American family, the second one is the deeply-held belief in spirituality and the third one is the sense of responsibility. In the story of the eagle feathers and what follows, all the subthemes are in evidence, but perhaps more particularly the second:

The second subtheme, spirituality, was described as being part of something greater than oneself that gave purpose and meaning to life. Each woman expressed her spirituality in a high personal and individualized way and spoke of it as a journey and continuous exploration, never as a destination that was fixed in a place or time. (Barkdull, 2009, pp. 129-130) 


\section{Discussion and Analysis}

\subsection{The first turning point for Omakayas in The Porcupine Year: the eagle}

Deydey assembles everyone to build a sweat lodge to give Omakayas her new name as a warrior after she fights with the eagle which symbolizes the courage. The new name is Ogimabinesikwe, the name of her father's grandmother, which refers to the spirit Leading Thunderbird Woman, who now will know and protect Omakayas. Omakayas accepts the name with pride, but declares she still wants to be called Omakayas. Although she might not totally know who she is, she has chosen to remain Omakayas, to devote her heart and soul to being a part of her family. The fight with the eagle, was a significant turning point in her life, officially ending her childhood and leading her to the next stage of growing up. Omakayas's consciousness of a new identity, goes hand in hand with Native American spirituality, but also with her sense of humility.

\subsection{Turning point for Omakayas in The Porcupine Year: LaPautre's robbery}

Another turning point later in the book is Albert LaPautre's robbery. The family is on their way North, to Lake of the Woods, where they have relatives. They have worked hard over the summer and have plenty of dried meat and furs; they will not come to their relatives as paupers. They meet LaPautre, Omakayas's uncle, and at first are happy to see him. But he has not come to greet them. With the band of robbers who accompany him, he takes everything the family has, even the two white orphan children they have rescued, to sell for money. It is a betrayal of the first magnitude. Erikson writes that "[t]he adolescent ... is ready to be confirmed by rituals, creeds, and programs which at the same time define what is evil, uncanny, and inimical" (1993, p. 263). Richard Stevens (1983) uses Erikson's theory to point out that an adolescent needs to re-examine right and wrong "in the face of an often potentially hostile world" (p. 49). In the previous chapters of the story, it is clear that the family treats everyone and everything around them kindly, and without distrust. LaPautre's raid is a bolt from the blue, and leaves them with nothing. They "had faced starvation before, but never without their guns and traps" (Erdrich, 2008, p. 101). Omakayas watches as her folks physically and mentally change. In addition to starvation Deydey becomes blind in both eyes, a result of fighting with the robbers, and Nokomis weeps, which Omakayas has never seen her do before. But her mother Yellow Kettle's bad temper has improved during this crisis. It "seemed that she [Yellow Kettle] was firmer with herself and more in control when her little family was in danger" (ibid., p. 105). Omakayas's brother Pinch, now called Quill for his porcupine, also suffers "terribly from his worst nightmare - nothing to eat" (ibid., p. 112). As well, the ceremony Deydey had planned for Omakayas for her bravery fighting with the eagle, cannot be held. LaPautre has managed to ruin this too. He is "evil, uncanny, and inimical", the bad man in the world that Erikson states that an adolescent will discover (1993, p. 263). But everyone in the extended family harbors hatred for LaPautre. He can no longer be affirmed by his society because of his own actions. In this situation Omakayas's own negative feelings emerge. It is "terrible" for her "to see Deydey stumbling about, his eyes wrapped, or hanging on to the arm of Yellow Kettle" (ibid., p. 99), and in her own heart, "there was no revenge harsh enough for what LaPautre had done" (ibid., p. 100).

\subsection{Turning point for Omakayas in The Porcupine Year: Learning a lesson form her brother Quill}

Omakayas intends to do something to help her family. She tries to catch rabbits for food but her snares don't seem to work. She is surprised to see her little brother changing her snares in secret: "Omakayas . . saw that Quill was gently adjusting each one of them. He was helping her without telling her! Omakayas turned away, not sure whether to be grateful or ashamed" (ibid., p. 104). Quill is her little brother, to whom she should give knowledge, but he already knows more about snares than she does. After hearing Deydey's story about his past ill treatment by his own (white) father, Quill expresses his thoughts in response to the story and Omakayas feels that this is not Quill that she knows. After returning from his capture by the Bwaanag (the Lakota tribe), Quill "had become surprisingly quiet and serious, and he avoided Omakayas the way boys, as they grew older, avoided their sisters" (ibid., p. 92). When Quill says he will take revenge on LaPautre, "the cold nerve in his voice chilled Omakayas and [i]t was as if her brother was becoming a different person" (ibid., p. 109). Omakayas longs to act like an older sister, to guide her brother and teach him right from wrong, even as she wishes they could tease each other the way they used to. The mature Quill makes her feel awkward and she cannot play the ideal role that she wishes to. According to Jungian theory:

The persona is the social mask worn by people. Its function is to hide the true person (the Jungian "self") from others. The persona is the role we play. One that is acted to create in others the opinion we wish them to have of us. We all find it necessary to hide ourselves to greater or lesser extent . . . We might be ashamed or victimized. The major risk presented by the persona, however, is that the ego (in Jungian psychology, "the conscious mind") may become so identified with the mask, that we lose contact with our true selves" (Notterman, p. 154). 
After Quill's adjustments, Omakayas's snares catch two rabbits. Omakayas wishes to secretly learn to set snares better, because "[s]he was the older sister [and] was supposed to be the one with the knowledge" (Erdrich, 2008, p. 106). This is the role she feels she must play, and she is failing to do so. She eventually turns to Deydey to teach her how to set a good snare. What he tells her instead are his thoughts on LaPautre's raid:

One of the things that I regret most, stolen from us by LaPautre, was my medicine bag. I was keeping your feathers in that bag. Also, the stone pipe that belonged to my father and his father before him. I will have to make a new pipe. I will have to travel to the land of the Bwaanag in order to trade for their stone, or I will have to use the black stone that we find farther north. I miss that pipe of my fathers very greatly. And I also miss the four feathers that you gave me. You were so brave in taking them. (ibid., p. 107)

Omakayas realizes that every member of the family is physically and mentally weak; and that Deydey in particular, her strong father, needs more care. Deydey cares nothing about presenting a strong face to his daughter. Instead, he says "my girl, if I do not recover, I want you to live a strong life" (ibid. p. 107). Omakayas realizes that she has to swallow her pride as an older sister and help her family get through this hard time. Instead of competing with Quill she should cooperate with him to catch the rabbits - the food her family needs to live on. Thus, Omakayas takes another step toward maturity when she asks for Quill's help. Despite his weakness, Deydey has helped Omakayas move towards psychological maturity and a spiritual awakening.

As we have seen, Barkdull (2009) posits three supporting characteristics or subthemes to his identity theme of "knowing who I am", which manifest as follows:

The first subtheme, connectedness, encompassed relational aspects of family, tribal affiliation or affiliations, and ..."Indianness." Connectedness evoked a sense of physical and/or emotional closeness, of belonging...The second subtheme, spirituality, was described as being part of something greater than oneself that gave purpose and meaning of life... a significant aspect of knowing "who I am" [the third subtheme] was an extremely strong sense of duty. (pp. 128-29)

Omakayas acts on all of them after LaPautre's raid, as she struggles to become the ideal self who can help her family. Part of who she is, is a person trying to relieve and heal the members of her family; her sense of connectedness to them is also to something greater than herself, and the sense of duty follows naturally from it.

\subsection{Michael Garrett and J. T. Garrett's observations on Native American children's education}

The attack of Albert LaPautre is definitely a disaster, but it makes Omakayas's family even closer, especially the women. Women do all the work wholeheartedly to keep the family in one piece, taking care of Deydey, who has been blinded from the fight. Without even realizing it, Omakayas is learning from everything going on around her while working with her mother, grandmother, and even her younger brother. As Michael Garrett and J.T. Garrett (2003) suggest:

According to traditional beliefs, true learning occurs when people are respected and accepted for who they are and what they uniquely contribute to the circle of life, which consists of the social and natural surroundings. Thinking in terms of family/clan/community rather than in terms of " $\mathrm{I} / \mathrm{me}$ ", many Native American children learn by seeing, doing, and cooperating (p. 68).

Significantly, in Native American culture elders have important roles in educating children, and the process is more through shared activities than lectures. The elders are responsible for "directing children's attention to the things with which they co-exist (family, community, trees, plants, rocks, animals, elements, the land) and to the meanings of these things" by using "the traditional way" (ibid., p. 74). This way of education instills the belief that "they [the children] are a part" of the community which is also "a part of them," at the same time, children are taught about "the circular (cyclical) motion of life, and "the customs and traditions of their people" (ibid. p. 74). As Brianne Alia May Grant (2009) mentions that "[a]lthough the traditional education of Omakayas by Elders and adult community members in The Porcupine Year is unaffected by Western education systems, her education is affected by colonialism and the loss of the community's traditional territories in the Midwestern region of the United States" (p. 7). Omakayas can preserve her tradition and culture from her elders, but the land loss also gives impact on her in the process of education and self-development. Simultaneously, "the community struggles that occurred due to loss of land and political oppression" are also very crucial for Omakayas especially facing his uncle LaPautre's raid (ibid., p. 14).

Garrett and Garrett go on to state that Native Americans believe that "openness and patience" are essential for teaching (2003, p. 68). In general, children accompany adults who are working as observers or helpers whose main purpose is to absorb as much as possible. Accordingly, time for reflection is an important part of learning, as well as practicing those skills. During their work with older relatives, few verbal instructions are included, leaving more room for children to observe and ask their own questions: 
Many Native American children are deliberately taught skills and important life lessons, both in the natural surroundings and in the home environment, at an earlier age than are children in many other cultures. Whether indoors or outdoors, each of these experiences begins with careful observation of the surroundings and the skill to be learned (ibid. p. 68).

\subsection{The significance of the elder Native American's education to children}

In The Porcupine Year, Omakayas's grandmother, Nokomis, is trying to replenish their supplies of food, medicine and clothes by collecting whatever she can find from the swamp:

Omakayas spent each day of that moon in the great medicine swamp with Nokomis. In her later years, she would realize that this was when she has received the greatest part of her education. She learned all that Nokomis knew. This was how she became a healer (Erdrich, 2008, p. 104).

Additionally, the elder Native Americans educate their children by specifying that "it is more important to experience and understand a process in life, rather than to focus on the outcome of the process" (Garrett, 2003, pp. 73-4). Thus, the whole event and the terrible aftermath of LaPautre's robbery become a life lesson to Omakayas. Not only does she learn how dark a man's heart can be, she also learns from her older relatives how to deal with the crisis and how to survive such a disaster.

\subsection{Turning point for Omakayas in The Porcupine Year: the death of Old Tallow}

The most distressing aftereffect of the raid for the twelve-year-old Omakayas is Old Tallow's death. When the whole family is near death from starvation, and even the strongest men are so weakened they can barely move, this strong old woman goes out alone, saying "my relatives, ... it is time for Old Tallow to hunt the bear!" (Erdrich, 2008, p. 116). Old Tallow never returns. She and the bear are found standing in the snow, Old Tallow's spear in the bear, the bear's claws in her neck. The sight will be engraved on Omakayas's memory all of her life. Her grief is profound: "darkness took her. . for a long time she knew nothing. She did not want to emerge. She wanted to stay in the darkness with the old woman she had loved" (ibid., p. 119). She is unwilling to shake this dark terrible mood; neither does she look for any consolation. Even as she eats the bear broth, "nothing could fill the absence that had opened around her heart" (ibid., p. 121). She can't accept Old Tallow's death and "She wanted Old Tallow back, and every morning when she woke and realized that Old Tallow was gone, she turned her face to the wall in despair" (ibid., p. 121)

\subsection{The significance of oral stories for children}

Oral tradition plays a very significant role in Native American's culture, tradition and education. Grant (2009) especially points out that "Louise Erdrich inserts stories of the grandmother and of the Ojibwe culture in a different font and text size to emphasize the oral tradition and the importance of storytelling" (p. 69). Nokomis tells Omakayas a story called "The Bear Girl Makoons" to distract her from her sorrow. Later, after Omakayas's first menarche comes, Nokomis tells her Old Tallow's story as "The Girl Who Lived With Dogs". The two stories have a similar structure. Neither Makoons nor Old Tallow belong to the place where they live. Makoons is a bear raised in a human family. Her human sisters marginalize her and try to shake her off on their journey to a faraway village. As for Old Tallow, she is sold to a trapper, Charette, who treats her like one of his dogs (and he treats his dogs very badly). Both girls are still willing to help those who have mistreated them. Makoons helps her sisters keep from being killed by the bad medicine woman. After Makoons changes into a beautiful woman, she only wants to go home to care for her old parents, even though her husband begs her to come back to him. When Charette is weak and sick he is terrified when Old Tallow suddenly stands up in front of him. But she treats him kindly instead of exacting revenge. Erikson (1968) points out:

[A] comparative view of child training, ... suggests a fact most important for identity development, namely, that adults by their own example and by the stories they tell of the big life and of what to them is the great past, offer children of this age an eagerly absorbed ethos of action in the form of ideal types and techniques fascinating enough to replace the heroes of the picture book and fairy tale (p. 120).

Through telling the stories of the bear girl Makoons and Old Tallow, Nokomis alleviates Omakayas's pain and gives her two heroines to model herself on. As well as stories, Omakayas has witnessed Old Tallow's act of heroism, killing a bear for them to eat at the cost of her own life. Old Tallow displayed complete love, selflessness and generosity, and is a role model that Omakayas wants to imitate. Whether Omakayas will follow the moral of Nokomis's stories, and forgive those who have done harm, is not yet clear. Before the family head north in search of Omakayas's aunt Muskrat, Omakayas goes to Old Tallow's tree and swears revenge on LaPautre who "had caused them all to starve" but she doesn't "blame the bear for the death of Old Tallow" (Erdrich, 2008, p. 134). A less intense but thornier struggle awaits Omakayas at their new camp. 


\subsection{Turning point for Omakayas in The Porcupine Year: Shadow archetype from Two Strike}

When Omakayas's family arrives at Muskrat's house, Omakayas has to hide her antipathy toward her cousin Two Strike, who bosses everyone around. When she returns from hunting with Animikiins, the boy Omakayas has begun to care for, "Two Strike threw the animals at the feet of her cousins and ordered them in a loud voice to prepare the meat" (ibid., p. 151). Then she says to Omakayas: "Little Frog girl, bring me a nice, hot cup of tea!” (ibid., p. 151). Even Two Strike's mother, Muskrat, is ordered to serve her tea. Omakayas is obedient to the wishes of Two Strike, who hunts as well as a man and kept her family fed after LaPautre left them. Omakayas even hides her romantic attachment to Animikiins, who is spending more and more time hunting with Two Strike. Wanting to be amicable, Omakayas says nothing of what she feels; but that does not prevent her from feeling it. As Murray Stein states in his interpretation of Jung's studies on the shadow archetype:

Most people do not know that they are quite as self-centered and egotistical as they are, and they want to appear unselfish and in control of their appetites and pleasures. People tend rather to hide such traits from others and themselves behind a facade that show them to be considerate, thoughtful, empathic, reflective, and genial. The exceptions to this social norm are those who have formed a "negative identity" — the black sheep who are proud of their greed and aggressiveness and flaunt such traits in public, while in their hidden shadow side they are sensitive and sentimental" (Stein, 1998, p. 107).

When Two Strike's feelings are hurt by Animikiins, Omakayas thinks "why should she care if Two Strike felt hurt? She deserved it. Omakayas looked down at her lap to hide her own expression" (Erdrich, 2008, p. 160). She doesn't even want to pity her cousin.

Two Strike seems to exemplify the "negative identity" in the above quote, as she has taken on the negative qualities of arrogance and pride. Garret and Garrett writes that "[b]oasting of one's accomplishments and loud behavior that attracts attention to oneself are discouraged in Native American tradition" (Garrett, 2003, p. 73), and Native American elders "today continue to teach the value of humility as a strength in the family, clan and tribe" (ibid. p. 73). Two Strike's rudeness finally provokes a response from Nokomis, who points out that "Old Tallow hunted for us all of her life, yet never once did she order me to prepare something for her. Everything I gave her, she received as a gift. Never once did she treat me with disrespect" (Erdrich, 2008, p. 152). Omakayas, who is capable of appearing unselfish, can at least avoid being judged as evil, but her feelings for Two Strike are anger at her behavior, envy of her accomplishments, and jealousy over her relationship with Animikiins.

\subsection{Omakayas's meaningful occasions to maturity: Love for Animikiin}

Nokomis tells Omakayas Old Tallow's story as her first moon comes. The story raises the question "what do you do when a person who has been cruel to you becomes helpless?" (ibid., p. 177). Omakayas remembers that when Old Tallow was alive, she had treated everyone with generosity. She fed her dogs better than she fed herself; and she had rescued Omakayas as a baby because she sensed a baby's loneliness.

For the suffering of the noble old woman who had loved Omakayas better than her dogs was a mysterious thing. The pain and degradation had made Old Tallow stronger, but also kind to the helpless. Old Tallow had been just. She had known exactly how long to live. When her life would count the most, she freely gave it. She was proof, in her love, of a love greater than we know. For how, in that heart treated worse than a dog's, had the capacity for such deep kindness grown? (ibid., p. 179)

Old Tallow's altruism and selflessness set an ideal example for Omakayas. But it is still difficult to follow in the tracks of the old woman she loved so much.

In the classic Bildungsroman the protagonist goes through several phases of life, encountering challenges which lead to maturity. Love and sexual attraction are part of these challenges. Omakayas's feelings are stirred by Animikiins, a boy who has been travelling with her family. The first sign of her regard for Animikiins is when she gives him her "precious strings of red beads" when he and her brother decide to travel in advance of the family (ibid., p. 77). The red beads "could almost be a love gift" (ibid., p. 77), as they represent a kind of blessing and protection, and show Omakayas's concern for Animikiins. Later, Animikiins plays the flute for her, indicating that he has feelings for Omakayas as well. Omakayas becomes so distracted that she cannot sleep, because Animikiins's image is ever present in her mind - a sign that she is growing up, and going through the first awakening of love.

Their arrival at the camp where Two Strike lives changes everything. Two Strike is a heroic kind of person, a young girl who is such an excellent hunter that she saves her family during the harsh winter. Although Two Strike is both disrespectful and boastful, which are discouraged in Native American culture, she is admired for her hunting prowess as well as her ability to take care of her family. Her bad behavior is allowed, much to the annoyance of the other young 
women her age. Even worse, Animikiins spends a great deal of time off hunting with her. Omakayas harbors dark feelings toward Two Strike, but with a role model like Old Tallow, who forgave much greater hurt, she does not simply succumb to them, but struggles with them.

\subsection{Turning point for Omakayas in The Porcupine Year: Menarche}

The other important event in Omakayas's life at this time is her first menarche, which is deemed so significant that her family holds a ceremony for her. F. L. Gross (1987) explains Erikson's theory about the importance of puberty thus:

What is unique about the stage of Identity is that it is a special sort of synthesis of earlier stages and a special sort of anticipation of later ones. Youth has a certain unique quality in a person's life; it is a bridge between childhood and adulthood. Youth is a time of radical change - the great body changes accompanying puberty, the ability of the mind to search one's own intentions and the intentions of others, the suddenly sharpened awareness of the roles society has offered for later life. (p. 47)

Writing about the supernatural power associated with menstruation, Victoria Brehm (1996), states that: "When Ruth Landes studied Ojibwa women, she noted that women's visions were often spontaneous rather than encouraged" (p. 686). Now that she has stepped on this "bridge" to becoming a woman, Omakayas does have a spontaneous vision. Omakayas already has showed her maternal instincts much earlier, by her caring and love for her younger brothers and even the two white children her family had hoped to adopt. She takes another giant step toward maturity when she has a vision about her father and the priest that allows the family to find the island where the two of them have been stranded. But it isn't until Omakayas is being publically thanked, and Nokomis mentions that this gift of vision is not something to use for herself that Omakayas begins to face her own shadow, and to see that she is in danger of becoming prideful. At this critical juncture, she sneaks a look at her cousin Two Strike, hoping to surprise a look of envy on the face of her vanquished rival. Instead she sees only admiration; Two Strike wholeheartedly admires Omakayas for her visions, for a talent that Two Strike lacks. Omakayas realizes that in some way it was her own envy that made Two Strike into an enemy, and that despite her flaws, in this instance Two Strike has a larger heart than Omakayas does. At this point Omakayas confronts her own shadow, and owns it. In this confrontation with and acceptance of her own shadow, Omakayas is strengthened as a person, which bodes well for her new role as a healer.

\section{Conclusion}

This is the culmination of Erdrich's story about a Native American girl's coming of age, as well as the culmination of the "year of danger and love, sacrifice and surprise - that porcupine year (Erdrich, 2008, p. 182). Omakayas has been supported and educated throughout the story by her father, mother, and grandmother, as well as by the actions and stories of Old Tallow. At the end of her year of adolescent and spiritual awakening, Omakayas has become a strong young woman with a wiser mind and a more truly humble attitude. 


\section{References}

Barkdull, Carenlee. (2009). Exploring Intersections of Identity with Native American Women Leaders. Journal of Women and Social Work, 24(2), 120-136.

Braendlin, Bonnie Hoover. (1983). Bildung in Ethnic Women Writers. Denver Quarterly, 17(4), 75-87.

Brehm, Victoria. (1996). The Metamorphoses of an Ojibwa Manido. American Literature, 68(4), 677-706. http://dx.doi.org/10.2307/2928134

Buckley, Jerome Hamilton. (1974). Season of youth: The Bildungsroman from Dickens to Golding. Cambridge: Harvard University Press.

Dubas, Judith Semon, \& Petersen, Anne C. (1993). Female pubertal development. In Max Sugar, M. D., (Ed.), Female adolescent development (pp. 3-26). New York: Rrunner/Mazel, Inc.

Erdrich, Louise. (2008). The porcupine year. New York: HarperCollins.

Erikson, Erik H. (1993/1950). Childhood and society. New York: W. W. Nortons.

Erikson, Erik H. (1968). Identity, youth, and crisis. New York: W. W. Norton.

Ferguson, Mary Anne. (1983). The female novel of development and the myth of psyche. In Abel, Elizabeth, Hirsch, Marianne, Langland, Elizabeth, et al. (Eds.), The voyage in: fictions of female development (pp. 228-243). Hanover and London: New England University Press.

Garrett, Michael, \& Garrett, J. T. (2003). Native American faith in America. New York: Facts

On File, Inc.

Grant, Brianne Alia May. (2009). Where hope lives: An examination of relationship between protagonists and education systems in contemporary north American young adult fiction. MA thesis. The University of British Columbia. Print.

Gross, F. L. (1987). Introducing Erik Erikson: An invitation to his thinking. Lanham, MD: University.

Jung, C. G. (1982). Aspects of the feminine. Trans. R. F. C. Hull. New York: Princeton UP.

Labovitz, Esther Kleinbord. (1998). The myth of the heroine: The female Bildungsroman in the twentieth century: Dorothy Richardson, Simone de Beauvoir, Doris Lessing, Christa Wolf. New York: P. Lang.

Notterman, Joseph M. (1985). Forms of psychological inquiry. New York: Columbia University Press.

Rozakis, Laurie E. (1999). Complete idiot's guide to American literature. New York: Alpha Books.

Smith, Sidonie, \& Watson, Julia. (2001). Reading autobiography: A guide for interpreting life narratives. Minneapolis: University of Minnesota.

Stein, Murray. (1998). Jung's map of the soul: An introduction. Chicago: Open Court.

Stevens, Richard. (1983). Erik Erikson, An introduction. New York: St. Martin's Press.

Thompson, Melissa Kay. (2001). A Sea of Good Intentions: Native Americans in Books for Children. The Lion and the Unicorn, 25(3), 353-74. http://dx.doi.org/10.1353/uni.2001.0038

Valaskakis, Gail Guthrie. (2005). Indian country:Essays on contemporary native culture. Wilfrid Laurier University Press.

Wolman, B. B. (1973). Dictionary of behavioral science. New York: Van Nostrand Reinhold. 